\title{
Imunobiologija transplantacije bubrega i mehanizmi djelovanja imunosupresivnih lijekova
}

\section{Immunobiology of kidney transplantation and mechanisms of immunosuppressive drugs}

\author{
Stela Živčić-Ćosić1,2, Zlatko Trobonjača $2^{2}$
}

${ }^{1}$ Klinički bolnički centar Rijeka

${ }^{2}$ Medicinski fakultet Sveučilišta u Rijeci

\section{*Dopisni autor:}

Prof. dr. sc. Zlatko Trobonjača, dr. med.

Zavod za fiziologiju, imunologiju i patofiziologiju, Medicinski fakultet Sveučilišta u Rijeci, Braće Branchetta 20/1, 51000 Rijeka

E-mail: zlatko.trobonjaca@uniri.hr

http://hrcak.srce.hr/medicina
Sažetak. Imunosni sustav obuhvaća imunost koju čini nespecifični (prirođeni) imunosni odgovor i specifičnu (stečenu) imunost koja se adaptivno razvija protiv stranih antigena. Presađivanje alogeničnog ABO-podudarnog bubrega prvenstveno stimulira specifičan imunosni odgovor usmjeren na peptidne antigene koji se predočavaju na donorskim stanicama u okviru molekula kodiranih glavnim sustavom tkivne podudarnosti MHC. Imunosni odgovor započinje prepoznavanjem antigena od strane limfocita $\mathrm{T}$, pri čemu je neophodno međudjelovanje T-staničnog receptora s peptidnim antigenima predočenim od antigen-predočnih stanica $i$ kostimulacijskog receptora $s$ ligandom na antigen-predočnim stanicama. Oba signala su neophodna za ulazak limfocita T u stanični ciklus, a nakon toga se unutarstaničnim prijenosom signala aktiviraju geni za proizvodnju i lučenje citokina. Aktivirani limfociti T, koji migriraju do presatka gdje induciraju akutni upalni odgovor, djeluju izravno citotoksično i potpomažu proizvodnju protutijela od strane limfocita B te odgovore odgođenog tipa preosjetljivosti inducirane makrofagima. Čimbenici ovisni i neovisni o aloantigenu pridonose efektorskim mehanizmima koji uzrokuju reakciju odbacivanja presatka. Značajan napredak na područjima imunobiologije i imunogenetike omogućio je sigurnije i uspješnije liječenje transplantacijom organa. Izuzetno je važno rano otkrivanje i sprječavanje reakcije odbacivanja presatka. Uz primjenu suvremenih imunosupresivnih lijekova rijetko se javlja teška reakcija odbacivanja posredovana limfocitima T. Najčešći uzrok gubitka funkcije presatka je kronična reakcija odbacivanja posredovana protutijelima koja su usmjerena na HLA antigene darovatelja. U radu prikazujemo mehanizme nastanka reakcije odbacivanja presatka posredovane stanicama i protutijelima, mjesta djelovanja imunosupresivnih lijekova te razvoj novijih strategija liječenja s ciljem daljnjeg poboljšanja preživljenja pacijenata i presatka.

Ključne riječi: HLA kompleks; imunobiologija transplantacije; presađivanje bubrega; reakcija odbacivanja presatka

Abstract. The immune system comprises the nonspecific (natural) immune response and the specific (aquired) immunity that has adaptively developed against foreign antigens. ABOcompatible kidney allotransplantation primarily stimulates a specific immune response against peptide antigens presented on donor cells by major histocompatibility complex (MHC) encoded molecules. The immune response begins with alloantigen recognition by $T$ lymphocytes, i.e. the T-cell receptor interaction with peptide antigens presented by antigenpresenting cells, and the costimulatory receptor interaction with its ligand on the antigenpresenting cell. Both signals are necessary for T lymphocytes to enter the cell cycle, then intracellular signalling leads to the activation of genes and secretion of cytokines. Activated $T$ lymphocytes migrate to the allograft where they induce an acute inflammatory response. They act directly cytotoxic and provide help to B lymphocytes for antibody production, and for delayed-type hypersensitivity responses induced by macrophages. Alloantigen-dependent and independent factors contribute to effector mechanisms which lead to allograft rejection. Remarkable advances in the field of immunobiology and immunogenetics have enhanced the safety and improved outcome after kidney transplantation. It is very important to early 
detect and prevent allograft rejection. With currently available immunosuppressive drugs, severe T-cell mediated rejection has become a rare event. The most common cause of graft failure is chronic rejection mediated by antibodies directed against donor HLA antigens. Herein, we review the mechanisms of cell- and antibody-mediated rejection, site of action of immunosuppressive drugs and recent development of treatment strategies aiming at further improvement of patient and graft survival.

Key words: allograft rejection; HLA complex; kidney transplantation; transplantation immunobiology

\section{UVOD}

Era transplantacijske imunobiologije započela je 1900-tih kada je Karl Landsteiner iz Beča otkrio krvne grupe. Pedesetak godina kasnije Peter Medawar s University Collegea u Londonu otkrio je aktivno stečenu imunosnu toleranciju u štakora i razjasnio stanične mehanizme reakcije odbacivanja (1953. godine) ${ }^{1}$. Istraživanja Josepha Murraya s Harvarda omogućila su 1954. godine prvu uspješnu transplantaciju bubrega jednojajčanog blizan$\mathrm{ca}^{2,3}$. U idućim desetljećima usavršavani su postupci presađivanja bubrega, kao i poslijetransplantacijsko liječenje, naročito razvojem lijekova protiv reakcije odbacivanja alogeničnog presadka.

Imunosni sustav vrlo je kompleksan, a razvio se tijekom evolucije kao odgovor na stalnu izloženost mikroorganizmima. On obuhvaća imunost koju čini nespecifični (prirođeni) imunosni odgovor i specifičnu (stečenu) imunost koja se adaptivno razvija protiv stranih antigena. Temeljna zadaća imunosnog sustava je, pored obrane od infekcije, održavanje genske i antigenske homeostaze organizma. Da bi imunosni sustav mogao izvršiti tu svoju temeljnu funkciju, mora biti sposoban razlikovati vlastite od stranih antigena. Prema vlastitim antigenima pokreće tolerogenu reakciju (reakciju tolerancije), a prema stranim antigenima imunosnu reakciju koja obuhvaća mehanizme kojima uništava i izbacuje strane patogene iz tijela ${ }^{4-6}$. Stečena imunost obuhvaća prepoznavanje antigena i specifičnu reakciju na njega te razvoj imunosne memorije limfocita $\mathrm{T}$ i limfocita B. Limfociti T prepoznaju antigen u obliku peptida vezanog za MHC bjelančevine (glavni sustav tkivne podudarnosti, MHC, od engl. major histocompatibility complex), a limfociti B koriste imunoglobulinske receptore kojima mogu prepoznati dijelove antigena nazvane antigenskim epitopima. Prirođeni i stečeni imunosni odgovor usko su povezani. Antigen-specifična aktivacija limfocita T vodi u proizvodnju i sekreciju citokina i kemokina koji potiču komponente prirođene imunosti, kao i specifične mehanizme proizvodnje protutijela te citotoksičnosti posredovane $\mathrm{CD}^{+}$stanicama. U ovaj sustav ugrađena je i proizvodnja komponenti komplementa koje su neophodne za cjelovitost imunosne funkcije ${ }^{7}$.

Napredak na područjima imunobiologije i imunogenetike te korištenje suvremenih imunosupresivnih lijekova omogućili su sigurnije i uspješnije liječenje transplantacijom bubrega. Značajno se smanjila učestalost reakcije odbacivanja posredovane limfocitima T te je vodeći uzrok gubitka funkcije presatka postala kronična reakcija odbacivanja posredovana protutijelima usmjerena na HLA antigene presatka.

Bubrežni presadak najčešće nije genski (antigenski) identičan darovatelju, pa zbog toga može pobuditi imunosni sustav primatelja na razvoj transplantacijske (imunosne) reakcije. Ova reakcija usmjerena je prvenstveno prema $A B O$-antigenima krvnih grupa, stranim HLA (humani leukocitni antigeni) molekulama te drugim stranim tkivnim antigenima poput $\mathrm{H}$-antigena (histocompatibility antigens), što su u biti antigeni sporednog sustava tkivne podudarnosti (minor histocompatibility complex) ${ }^{8}$. Izrazom MHC označavaju se geni, dok se za imenovanje proteinskih proizvoda koje ovi geni kodiraju koristi izraz HLA. Intenzitet transplantacijskog imunosnog odgovora određen je nizom različitih čimbenika, poput izražaja nepodudarnih HLA antigena, prisutnosti antigen-predočnih stanica u presatku (suputničkih leukocita) te reaktivnih protutijela u serumu primatelja prema tkivu presađenog bubrega koja su mogla nastati ranijom senzibilizacijom, primjerice anti-ABO i anti-HLA protutijela.

\section{ANTIGENI TKIVNE PODUDARNOSTI}

Među najjače transplantacijske antigene, koji predstavljaju cilj imunosne ili transplantacijske aktivnosti, spadaju HLA molekule ${ }^{9,10}$. Njih kodiraju od 


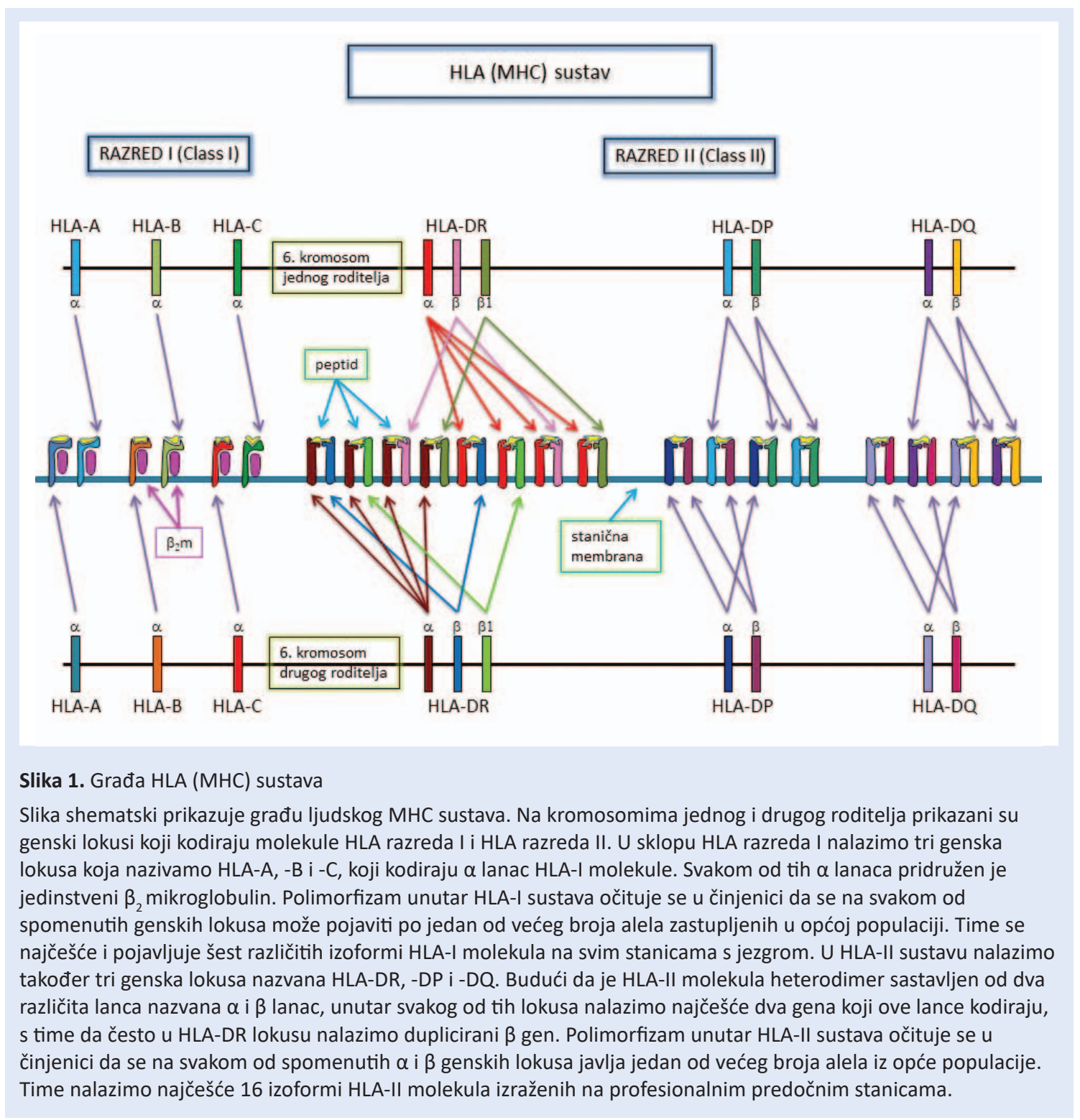

dvije skupine gena MHC sustava (MHC I i MHC II) koje karakterizira poligenija i polimorfizam ${ }^{11-13}$. Poligenija označava činjenicu da slični geni kodiraju proteinske proizvode koji obavljaju istu funkciju. Tako u MHC I sustavu nalazimo genske lokuse za HLA-A, HLA- B i HLA-C koji kodiraju izoforme HLA I molekula koje se nalaze na površini svih stanica $s$ jezgrom i trombocitima, a nema ih na eritrocitima. Naročito velik izražaj nalazimo na antigen-predočnim stanicana, uključujući dendritične stanice, makrofage i limfocite B te na vaskularnim endotelnim stanicama. MHC II sustav obuhvaća genske lokuse za HLA-DR, HLA-DP i HLA-DQ koji kodiraju izoforme HLA II molekula. Molekule HLA razreda II izražene su samo na antigen-predočnim stanicama, što zna- či na limfocitima $B$, dendritičnim stanicama i makrofagima te na timusnim epitelnim stanicama. Epitelne stanice i vaskularne endotelne stanice mogu izražavati HLA II molekule nakon izlaganja djelovanju proupalnih citokina kao što su IFN-y i TNF- $\alpha$. Ipak, HLA II molekule nalazimo uglavnom na profesionalnim predočnim stanicama, budući da je i funkcija ovih stanica izravno vezana uz izražaj ovih molekula. Polimorfizam sustava odnosi se na činjenicu da se na svakom od navedenih genskih lokusa može pojaviti jedan od većeg broja različitih alela koji se nalaze u općoj ljudskoj populaciji. Svaki alel kodira drugu izoformu HLA molekule, pa tako na HLA-A lokusu možemo naći, primjerice, alele HLA-A1 ili HLA-A2 ili HLA-A3 itd. 
Identificirano je skoro 27000 HLA-alela, a od toga preko 6000 samo na HLA-A lokusu. Stoga postoji mala vjerojatnost da dvije nesrodne osobe imaju iste HLA-molekule ${ }^{14}$.

Svaka osoba nasljeđuje po dva alela na svakom od MHC genskih lokusa razreda I i razreda II svojih roditelja (slika 1). Prema tome, djeca nasljeđuju po polovicu HLA molekula od svakog roditelja, što je haplotipna podudarnost prema roditeljima. Promatrajući djecu međusobno, postoji $25 \%$ vjerojatnosti da su HLA identični, tj. podudarni u oba haplotipa, $50 \%$ da su u jednom haplotipu podudarni i $25 \%$ da su potpuno nepodudarni. Manje promjene ovih udjela mogu nastati zbog križanja gena tijekom mejoze (engl. crossing over). Budući da je MHC molekula razreda II građena od dva različita lanca ( $\alpha$ i $\beta$ lanci), u polimorfnom MHC II sustavu na svakom genskom lokusu nalazimo po dva različita alela. Primjerice, na HLA-DR $\alpha$ lokusu nalazimo samo jedan od mogućih 29 alela koji se javljaju u cijeloj populaciji, na HLA-DR $\beta$ lokusu jedan od preko 3330 alela, na HLA-DQ $\alpha$ lokusu jedan od preko 280 alela, na HLA-DQ $\beta$ lokusu jedan od preko 1800 alela, na HLA-DP $\alpha$ lokusu jedan od skoro 200 alela, a na HLA-DP $\beta$ lokusu jedan od preko 1560 mogućih alela. Broj alela nije stalan, jer se gotovo svakodnevno otkrivaju nove genske izoforme. Unutar pojedinog lokusa MHC II, $\alpha$ i $\beta$ lanci različitih kromosoma mogu se međusobno kombinirati te time udvostručiti broj mogućih izoformi. Pored navedenog, pojedini $\beta$ aleli na MHC II lokusima (naročito na HLA-DR lokusu) mogu biti duplicirani, pa i triplicirani, dajući time još veći broj proteinskih HLA proizvoda. Najčešće nosimo 16 različitih HLA II izoformi.

Tijekom evolucije HLA molekule postale su izrazito polimorfne (velika varijabilnost $u$ aminokiselinskoj sekvenci peptida) i mogu vezati velik broj peptida mikroorganizama i time pružiti imunost protiv većine infekcija. Međutim, upravo je ova činjenica uzrok jake transplantacijske aloreaktivnosti, budući da HLA molekule nemaju samo ulogu u prezentaciji antigena nego su i same po sebi postale transplantacijski antigeni koji u primatelju presatka pokreću imunosni odgovor.

Određivanje HLA antigena molekularnim metodama rezultiralo je izrazitim porastom broja identificiranih HLA alela. Međutim, na HLA antigenima nalazimo epitope (slijed aminokiselina), s kojima mogu reagirati protutijela. Pojedine (zajedničke) epitope nalazimo na različitim HLA antigenima, što može rezultirati križnom reaktivnošću protutijela, odnosno vezanjem protutijela na jednu izoformu HLA antigena nakon što je proizvedeno protiv druge izoforme. Upravo zbog te činjenice, istraživanja u transplantacijskoj medicini ističu važnost podudarnosti u epitopima HLA antigena, na koja se vežu primateljeva donor-specifična protutijela (DSA = donor specific antibodies). Prema tome, kod presađivanja bubrega čak je važnija činjenica epitopske podudarnosti HLA antigena nego ukupna podudarnost u konstelaciji HLA sustava, čime se može smanjiti stvaranje DSA te povećati broj prihvatljivih

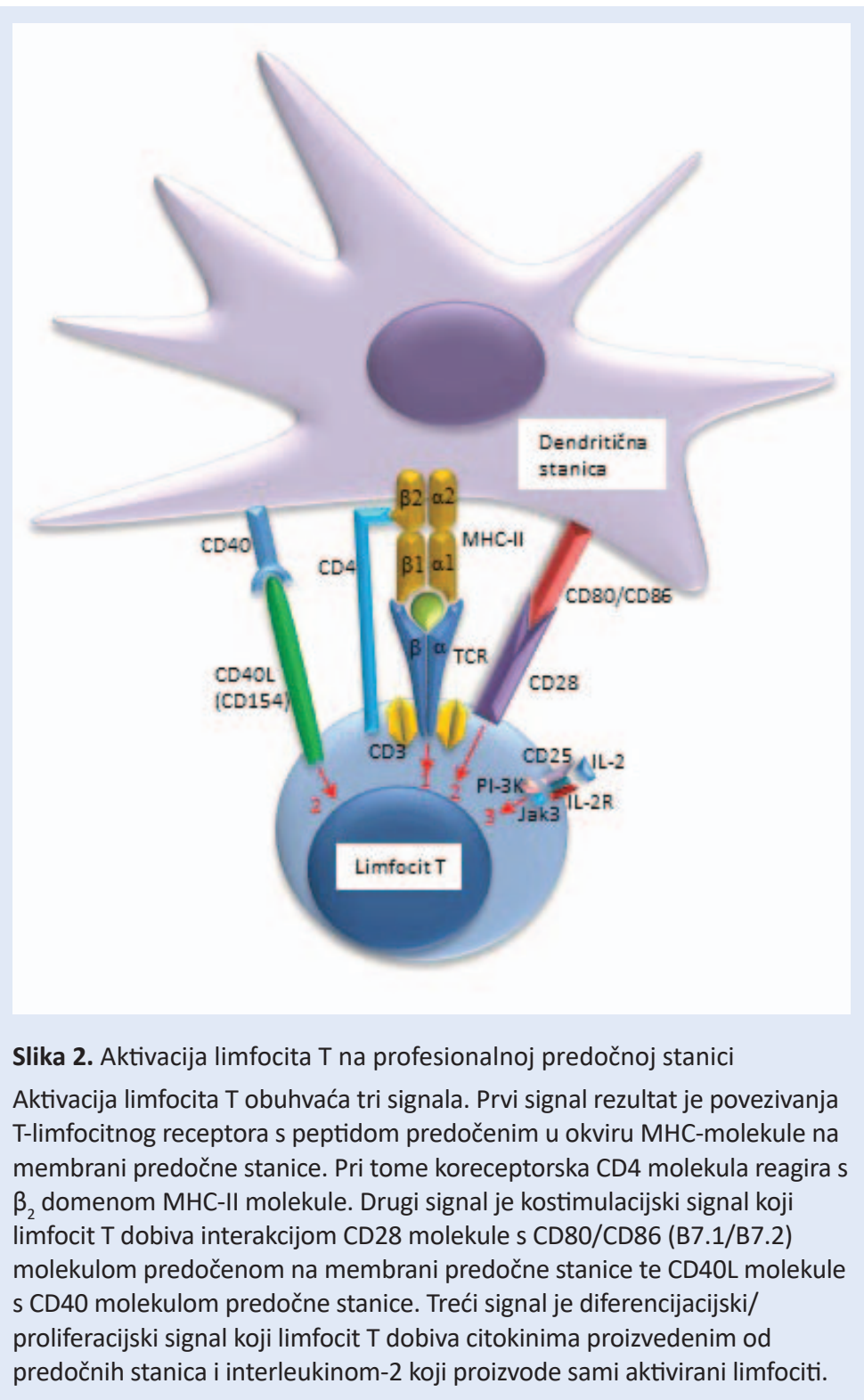


organa i poboljšati poslijetransplantacijski ishod $u$ pacijenata senzibiliziranih na HLA antigene ${ }^{13,15}$.

Na slici 2 shematski je prikazana građa MHC (HLA) sustava. HLA molekule razreda I sastoje se od jednog polimorfnog peptidnog lanca koji označavamo kao $\alpha$ lanac ili teški lanac te ubikvitarnog monomorfnog $\beta_{2}$-mikroglobulina. HLA $\alpha$ lanac sastoji se od domena $\alpha_{1}, \alpha_{2}$ i $\alpha_{3}$, od kojih $\alpha_{1}$ i $\alpha_{2}$ domene tvore žlijeb koji zovemo peptidna pukotina, u koji sjedaju peptidni antigeni veličine od 9 do 11 aminokiselina. Izražaj većeg broja izoformi molekula razreda I i razreda II povećava broj (repertoar) peptida koji se mogu predočiti putem ovih molekula. Za razliku od HLA-I, HLA molekule razreda II građene su od dva polimorfna lanca $\alpha$ i $\beta$, od kojih je svaki građen od po dvije imunoglobulinske domene $\left(\alpha_{1}, \alpha_{2}\right.$ te $\left.\beta_{1}, \beta_{2}\right)$. Domene $\alpha_{1}$ i $\beta_{1}$ tvore žlijeb za vezanje peptida veličine od 10 do 30 aminokiselina.

Peptide predočene u okviru HLA molekula razreda I prepoznaju citotoksični limfociti T svojim T staničnim receptorom u reakciji u kojoj se CD8 molekula veže na $\alpha_{3}$ domenu, dok peptide predočene u okviru HLA molekula razreda II prepoznaju pomagački $\mathrm{CD}^{+}$limfociti $\mathrm{T}$ u reakciji u kojoj se CD4 molekula veže na $\beta_{2}$ domenu. Podudarnost $u$ HLA razredu II osobito je značajna za dugoročno preživljenje presatka.

Neklasične (nepolimorfne) HLA molekule, poput HLA-G molekula, služe u regulaciji funkcije stanica prirodnih ubojica (stanice NK, engl. natural kiIler cells), odnosno poticanju njihovih inhibicijskih receptora. Aktivacijski receptori stanica NK prepoznaju molekule poput MIC-A (engl. MIC, MHC class I chain-related genes) i MIC-B, a inhibicijski su potaknuti funkcijom klasičnih i neklasičnih HLA molekula razreda I. Poznato je da povišena razina cirkulirajućih HLA-G molekula, koje normalno u placenti inhibicijom majčinih NK stanica pospješuju toleranciju fetusa, umanjuje rizik od odbacivanja bubrežnog presatka ${ }^{5}$.

Transplantacijska reakcija može se razviti i u slučaju potpune podudarnosti u HLA sustavu primatelja i darovatelja organa, ako oni nisu jednojajčani blizanci. Takva reakcija događa se temeljem razlike $u$ tzv. sporednim antigenima tkivne podudarnosti (engl. minor histocompatibility antigens ili $H$ antigens). Tada se reakcija odbacivanja presatka događa temeljem neizravnog puta prepoznavanja alogeničnih peptida deriviranih od onih bjelančevi- na koje nisu identične u tkivima darovatelja i primatelja. Najčešći izvor ovih peptida su HLA molekule, iako mogu biti i druge bjelančevine, poput nekih enzima ${ }^{5}$. Pored navedenog, postoje tzv. H-Y antigeni koji mogu posredovati odbacivanje muških presadaka u ženskim primateljima te polimorfne mitohondrijske bjelančevine koje također mogu poticati reakciju odbacivanja antigena ${ }^{5}$. Ovi se peptidi prepoznaju u okviru HLA-I molekula sa strane primateljevih $\mathrm{CD} 8^{+}$citotoksičnih limfocita $\mathrm{T}$, čime dolazi do razaranja presatka, međutim, ovi peptidi ne dovode do stvaranja aloantitijela ${ }^{16}$.

\section{ANTIGENI KRVNIH GRUPA}

ABO nepodudarnost značajna je prepreka za presađivanje bubrega. Strukture slične ABO antigenima nisu prisutne samo na eritrocitima, nego i na stanicama drugih tkiva. Budući da već u prvim godinama života stvaramo prirodna protutijela na ove strukture, temeljem odgovora na

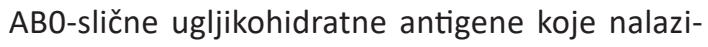
mo, primjerice, u hrani ili u crijevnim bakterijama, ABO-nepodudarnost razvija se vrlo rano. Postojanje ovih protutijela u serumu primatelja vodi u razvoj hiperakutne reakcije odbacivanja ABO nepodudarnog presatka razaranjem endotela krvnih žila, uz pokretanje mehanizma zgrušavanja krvi te hemoragijsku nekrozu presatka, i to unutar nekoliko minuta do nekoliko sati od presađivanja. Ova reakcija danas je izuzetno rijetka, budući da se kod transplantacije bubrega vodi računa o $A B O$ podudarnosti, ili se provodi postupak desenzibilizacije primatelja prije transplantacije. Za razliku od toga, Rh nepodudarnost nije prepreka za transplantaciju, budući da RhD antigen nije izražen na stanicama koje ne pripadaju eritrocitnoj lozi.

O postojanju $A B O$ nepodudarnosti treba voditi računa kod pacijenata koji su primali transfuzije krvi, jer mogu biti senzibilizirani na eritrocitne antigene i u serumu posjedovati tzv. iregularna antieritrocitna protutijela. Da bi se u pacijenata s kroničnom bubrežnom bolesti izbjegla senzibilizacija na leukocitne $\mathrm{i}$ eritrocitne antigene, anemiju treba liječiti eritropoetinom i, u slučaju potrebe za transfuzijom, primjenjivati filtriranu krv kojoj su odstranjeni leukociti te davati krv koja je podudarna u što većem broju eritrocitnih krvnih grupa. 
IMUNOSNO PREPOZNAVANJE BUBREŽNOG PRESATKA I PODVRSTE LIMFOCITA T

Limfociti T su podvrsta limfocita karakterizirana izražajem T limfocitnog receptora i CD3 kompleksa. Dijelimo ih na tri osnovne podvrste: pomagački, citotoksični i regulacijski limfociti T. Pomagačke limfocite $\mathrm{T}$ (engl. $T$ helper) nadalje dijelimo na Th1 limfocite, Th2 limfocite, Th17 limfocite i tzv. folikularne pomagačke stanice ili $\mathrm{T}_{\mathrm{FH}}(\mathrm{FH}$, engl. follicular helper $)^{17}$. Limfociti prolaze nekoliko razvojnih faza u tijeku svog antigenom potaknutog sazrijevanja koje obuhvaćaju diferencijaciju i proliferaciju stanica. Mirujuće imunokompententne stanice nazivamo djevičanskim ili neiskusnim stanicama, koje nakon kontakta s antigenom predočenim na antigen-predočnim stanicama prelaze $u$ aktivirane stanice. One se razlikuju od djevičanskih stanica po izražaju visokoafinitetnog interleukin-2 receptora (IL-2R) i proizvodnji citokina, među kojima dominira interleukin-2 (IL-2). Završetkom sazrijevanja limfociti ulaze u posljednju razvojnu fazu efektorskih stanica koje nakon izvršavanja određenih imunosnih funkcija odumiru apoptozom. Iz reakcije zaostaju samo memorijske stanice $\left(T_{M}\right)$ koje nisu u potpunosti diferencirane do efektorske razine i kao posebna podvrsta stanica u ovom obliku mogu postojati dugi niz godina. U slučaju ponovnog kontakta $s$ istovrsnim antigenom ubrzano prolaze korake završne diferencijacije i dosežu efektorsku razinu te time stječu sposobnost neutralizacije antigena, odnosno izvršavanja imunosti. Obično $T_{M}$ dijelimo na dvije podvrste, centralne i efektorske memorijske stanice. Centralne memorijske stanice cirkuliraju po tijelu i imaju proliferacijski kapacitet, dok efektorske memorijske stanice pretežito nalazimo u nelimfatičkim tkivima i slezeni, a imaju veći kapacitet za razvoj efektorskih funkcija kao što su lučenje IFN-y te ubijanje ciljnih stanica funkcijom perforina i granzima. Osim indukcije aloantigenima, $T_{M}$ nastaju i nakon cijepljenja, a postoji mogućnost križnog reagiranja s aloantigenima.

Pomagački limfociti T prepoznaju strane antigene izravnim te puno rjeđe neizravnim putem ${ }^{18}$. Izravno prepoznavanje podrazumijeva reakciju pomagačkih limfocita $T s$ alogeničnim (stranim) HLA molekulama izraženim na predočnim stanicama iz tkiva presatka. S druge strane, neizravni put prepoznavanja obuhvaća prepoznavanje antigenskih peptida, oslobođenih iz presatka i povezanih s HLA molekulama razreda II na predočnim stanicama primatelja, od djevičanskih limfocita $T$ primatelja. Antigenski peptidi nastaju od bjelančevina oslobođenih iz presatka i vežu se kao alopeptidi za HLA molekule na primateljevim antigen-predočnim stanicama te prikazuju neiskusnim limfocitima T. Ova reakcija identična je reakciji koju nalazimo tijekom predočavanja antigenskih epitopa mikroorganizama. U oba slučaja prepoznavanja antigena nastaju aktivirani limfociti T koji, u slučaju alotransplantacije, mogu infiltrirati presadak te koordinirati njegovo imunosno oštećenje funkcijom makrofaga i drugih imunosnih izvršnih stanica. Među njih ubrajamo i citotoksične limfocite T koji mogu prepoznati alogenične HLA molekule razreda I te uz pomoć Th1 pomagačkih limfocita T ubijati stanice presatka. U imunosnoj reakciji značajnu ulogu igraju i stanice $\mathrm{T}_{\mathrm{FH}}$, koje svojim citokinima u limfnom tkivu primatelja usmjeravaju imunosnu reakciju na stvaranje protutijela protiv antigena presatka. Aloreakcija je izuzetno snažna i obuhvaća 2 - $10 \%$ klonova djevičanskih limfocita T. Ovako visoka aloreaktivnost proizlazi iz činjenice da se neidentični, a slični HLA aloantigeni darovatelja prikazuju imunosnom sustavu primatelja kao da su to vlastite HLA molekule izmijenjene stranim peptidom, pa svaki klon limfocita koji se može povezati s ovakvim aloantigenima imunosno reagira.

ANTIGEN-PREDOČNE STANICE, AKTIVACIJA LIMFOCITA T I STANICA NK

Profesionalne antigen-predočne stanice predočavaju antigen u okviru HLA molekula i obuhvaćaju populacije dendritičnih stanica, makrofaga i limfocita B. Razlikujemo dvije podvrste dendritičnih stanica, mijeloidne i plazmacitoidne. Dendritične stanice potiču od prekursora mijeloične loze u koštanoj srži, a mogu se i diferencirati od monocita djelovanjem citokina GM-CSF (engl. granulocytemacrophage colony-stimulating factor) i IL-4 ${ }^{19}$. Razlikujemo dendritične stanice u mirnom nezrelom stanju u tkivima, u razdoblju prije kontakta s antigenom. Tada posjeduju velik kapacitet za hvatanje antigena fagocitozom i endocitozom, a mali predočni potencijal odnosno nisku razinu izražaja 
HLA molekula. Međutim, nakon kontakta sa stranim antigenima dendritične stanice se aktiviraju, pojačavaju izražaj HLA molekula, odnosno sposobnost prerade i predočavanja stranih antigena potrebnih za aktivaciju limfocita T. Pojačavaju izražaj membranskih kostimulacijskih molekula potrebnih za kostimulacijski signal limfocitima T, a luče i citokine koji daju diferencijacijski signal limfocitima T. Nadalje, aktivirane dendritične stanice stječu i migracijski potencijal, otpuštaju se iz matičnog tkiva te limfnim tokom dospijevaju do sekundarnog limfnog tkiva, gdje se u T-ovisnim zonama udomaćuju i granaju, čime povećavaju mogućnost kontakta s antigen-specifičnim neiskusnim limfocitima T. Kod alotransplantacije, značajnu ulogu igraju, kako donorske dendritične stanice (suputničke stanice) u izravnom prepoznavanju, tako i primateljeve dendritične stanice u neizravnom prepoznavanju tkiva presatka.

\section{Aktivacijski, kostimulacijski i diferencijacijski signali u limfocitima T}

Za punu aktivaciju, diferencijaciju i proliferaciju limfocita potrebna su sva tri signala. Prvi (aktivacijski) signal limfociti $\mathrm{T}$ dobivaju preko $\mathrm{T}$ limfocitnog receptora i CD3 molekule, a drugi kostimulacijski signal putem receptora CD28, koji je normalno izražen na svim neiskusnim limfocitima $\mathrm{T}^{20,21}$. Molekula CD28 reagira s kostimulacijskim molekulama antigen-predočnih stanica B7.1 (CD80) i B7.2 (CD86), izraženim na njihovoj staničnoj membrani. Pored toga, molekule stanične adhezije (npr. integrini) pojačavaju vezanje aloreaktivnih limfocita $\mathrm{T}$ za dendritične stanice koje predočavaju aloantigen. Kostimulacijski signal dozvoljava stanici potpunu aktivaciju, a ovaj međustanični kontakt neophodan je za aktivaciju obje stanice koje međureagiraju. Tim signalom omogućuje se transkripcija ključnih gena potrebnih za proliferaciju limfocita T. Put kostimulacije može se blokirati novijim imunosupresivnim lijekom belatacept, fuzijskom bjelančevinom ljudskog imunoglobulina G i molekule CTLA-4 (engl. cytotoxic T lymphocyte antigen 4, CD152) $)^{22,23}$. Aktivirani limfociti $T$ nishodno reguliraju izražaj CD28 molekula, a započinju izražaj CTLA-4 molekule koja služi za suprimiranje odgovora ovih stanica u slučaju ponovnog prepoznavanja antigena na dendritičkim stanica. $U$ tom slučaju povezivanje CTLA-4 molekula na B7 molekule dovelo bi do apoptoze limfo$\operatorname{cita}^{24,25}$. Pored navedenih kostimulacijskih molekula, na limfocitima $B$, dendritičnim stanicama i makrofazima izražena je kostimulacijska CD40 molekula koja reagira s odgovarajućom CD40L (CD154) molekulom izraženom na membrani limfocita $\mathrm{T}^{26}$. Poticanje CD40 molekula dodatno pojačava izražaj B7 i proizvodnju citokina u dendritičnim stanicama. U kliničkim ispitivanjima, tijekom primjene anti-CD40 protutijela, primijećeni su ozbiljni tromboembolijski događaji, što je ograničilo njihovu primjenu. Istražuje se i blokada drugih mehanizama koji sudjeluju u fazi aktivacije stanica radi ometanja reakcije odbacivanja presatka, kao što je blokada limfocitnih funkcijskih antigena koji služe za povezivanje stanica u smislu adhezijskih molekula. Primjerice, važnu funkciju imaju adhezijske molekule LFA-1 i LFA-3 (CD2) izražene na limfocitima $T$, koje reagiraju $S$ ligandima ICAM1 i ICAM2 ${ }^{17}$.

Treći signal stanice dobivaju djelovanjem citokina podrijetlom iz antigen-predočnih stanica i aktiviranih limfocita T. Diferencijacija podrazumijeva usmjeravanje ovih aktiviranih stanica, napose proliferirajućih limfocita T, u posebne efektorske stanične podvrste koje obavljaju specifične imunosne funkcije. Među citokinima uključenim u diferencijacijski signal ističe se IL-2 kojega luče aktivirani pomagački limfociti T i koji, djelujući autokrino ili parakrino, dovodi do proliferacije prethodno aktiviranih limfocita T. Ovaj signal IL-2 isporučuje preko IL-2R slabog afiniteta, koji je sastavljen od lanaca $\gamma$ i $\beta$, i pogotovo putem IL-2R jakog afiniteta kojega izražavaju aktivirane stanice, a koji kao heterotrimer posjeduje i treći $\alpha$ lanac, CD25. Prijenos signala ovim putem mogu ometati anti-CD25 monoklonska protutijela baziliksimab i daklizumab ${ }^{5}$. Normalno IL-2 dovodi do klonalne ekspanzije antigen-specifičnih aktiviranih limfocita T. Pored IL-2, u proliferaciju i diferencijaciju limfocita $T$ uključeni su i brojni drugi citokini (IL-4, IL-7, IL-9. IL-10, IL-13, IL-15, IL-17, IL-21). Receptori nekih od navedenih citokina sadrže y lanac IL-2R, kojega zbog toga nazivamo zajednički y lanac (engl. common gamma chain). Temeljni citokini T limfocitnog odgovora obuhvaćaju citokine Th1 profila ( $\mathrm{Th}=\mathrm{T}$ helper) IFN- $\mathrm{\gamma}$, 
TNF- $\alpha$, TNF- $\beta$ i IL-2, zatim citokine Th2 profila IL-4 i IL-13, potom citokine Th17 profila (nekoliko citokina koje ubrajamo u IL-17 porodicu A-F) te $T_{F H}$ koji luče citokine IL-4 i IL-21 potrebne za stimulaciju limfocita B. Pored navedenih podvrsta, regulacijski limfociti $\mathrm{T}\left(\mathrm{T}_{\text {reg }}\right)$ tvore skupinu koja svojim citokinima suprimira imunosnu reaktivnost i promovira toleranciju prema vlastitim antigenima te sprječava nastanak autoimunosnih bolesti. Ove stanice to postižu lučeći citokine, poput čimbenika transformacije rasta TGF- $\beta$ (TGF, engl. transforming growth factor;) te IL-10 sa sličnim djelovanjem, i IL-35 koji sprječava razvoj Th1 i Th17 odgovora.

\section{Transmembranski prijenos signala}

Fosfataza kalcineurin igra značajnu ulogu u prijenosu signala, a može se inhibirati lijekovima takrolimus i ciklosporin A te time smanjiti aktivaciju limfocita T. Ova fosfataza normalno defosforilira citoplazmatski nuklearni faktor aktiviranih limfocita T (NFAT), čime omogućava njegovu translokaciju u staničnu jezgru, u kojoj on djeluje kao transkripcijski faktor ${ }^{27}$. NFAT omogućava prepisivanje gena za IL-2 i drugih gena diferencijacijskih citokina limfocita $\mathrm{T}$, kao i izražaj $\alpha$ lanca IL-2R. Ulaskom u stanicu ciklosporin i takrolimus vežu se na regulacijske bjelačevine nazvane imunofilini, pa se tako ciklosporin veže za ciklofilin a takrolimus za FKBP (FK binding protein), budući da se takrolimus još naziva i FK506. Nadalje se novostvoreni kompleks lijek-vezna bjelančevina veže na kalcineurin, čime suprimira njegovu fosfataznu aktivnost, a time onemogućava defosforilaciju NFAT kao i njegovu translokaciju u jezgru. Time se u konačnici blokira proces limfocitne aktivaci$\mathrm{je}^{28}$.

Bjelančevina mTOR, tj. cilj djelovanja rapamicina (mTOR, engl. mammalian target of rapamycin), koja je uključena u proliferaciju limfocita T, također je neophodna za transmembranski prijenos signala. Djeluje kao proteinska kinaza koja omogućava progresiju stanice kroz stanični ciklus od G1 do S faze, rast stanice te pokreće mehanizme autofagije u stanici. Blokada molekule mTOR postiže se imunosupresivnim lijekovima rapamicinom ili everolimusom ${ }^{29}$. Oni blokiraju proliferaciju limfocita $\mathrm{T}$ i povećavaju stvaranje $\mathrm{T}_{\mathrm{M}}$. Poveziva- njem molekule mTOR s drugim bjelančevinama nastaju kompleksi poput mTORC1 molekule koja regulira stanični metabolizam, tj. homeostazu i proliferaciju stanica, i predstavlja glavni cilj djelovanja rapamicina. Drugi kompleks mTORC2, koji inhibiraju veće koncentracije rapamicina, ima normalnu ulogu u organizaciji aktina i preživljavanju stanice. Plejotropne funkcije mTOR molekula i izražaj u brojnim vrstama stanica uzrokuju razlike u učinkovitosti rapamicina i visoku učestalost nuspojava.

Postoje još drugi putevi prijenosa signala, među kojima se ističe JAK-STAT (engl. Janus kinase-signal transducer and activator of transcription) koji je uključen u provođenje signala dobivenih od interferona, IL-2 i brojnih drugih citokina ${ }^{17}$.

\section{Stanice prirodni ubojice}

$\mathrm{U}$ imunosnoj reaktivnosti protiv presatka ističu se i stanice prirodne ubojice (NK, engl. natural kiIler). Ove stanice slične su citotoksičnim limfocitima T jer ubijaju ciljne stanice istim mehanizmom, iako se od njih razlikuju načinom aktivacije. Dok se citotoksični limfociti T aktiviraju posredstvom HLA molekula i njihovih T limfocitnih receptora, NK stanice aktiviraju se djelovanjem tzv. aktivacijskih receptora koji prepoznaju različite ligande na ciljnim stanicama. Pored ovih aktivacijskih, NK stanice imaju i inhibicijske receptore koji vežu vlastite molekule HLA razreda I. Puna aktivacija NK stanica uslijedi ako se potiču aktivacijski receptori, a izostaju inhibicijski signali zbog izostanka izražaja HLA molekula na ciljnim stanicama presatka koje bi trebale isporučiti inhibicijski signal. Zbog toga NK stanice infiltriraju presadak te vode u njegovo razaranje i odbacivanje.

\section{ULOGA LIMFOCITA B I PROTUTIJELA}

Hiperakutno odbacivanje, kao posljedica preformiranih anti-ABO ili anti-HLA protutijela, danas se javlja izuzetno rijetko, međutim, donor-specifična protutijela koja se stvaraju nakon presađivanja bubrega protiv HLA antigena, a ponekad i drugih non-HLA antigena darovatelja, uzrokuju slabije preživljenje presatka zbog akutne ili kronične protutijelima posredovane reakcije odbacivanja (ABMR, engl. antibody mediated rejection $)^{30}$. Ova humoralna reakcija često je praćena i reakcijom 
odbacivanja posredovanom limfocitima T (stanični tip odbacivanja). Limfociti B aktiviraju se nakon prepoznavanja antigena B-staničnim receptorom, uz pomoć $\mathrm{T}_{\mathrm{FH}}$ podvrste CD4+ limfocita $\mathrm{T}$ u sekundarnim limfnim organima. Vezanje B-staničnog receptora na antigen vodi u internalizaciju kompleksa antigena i receptora, čime se formiraju endosomi, a nakon toga i fagoendosomi u kojima se antigen razgrađuje do razine peptida. Peptidi se povezuju s HLA molekulama razreda II i endosomalnim transportom vraćaju na membranu lim-

Stečeni i prirođeni imunosni odgovor usko su povezani. Limfociti T specifično prepoznaju antigen vezan u obliku peptida za HLA molekule, dok limfociti B koriste imunoglobulinske receptore kojima mogu prepoznati sekvence aminokiselina u antigenskim epitopima. Stečena imunost također obuhvaća razvoj imunosne memorije limfocita $\mathrm{T}$ i limfocita B.

focita B. Tako predočeni u okviru HLA-II molekula prepoznaju se od $\mathrm{CD}^{+}$pomagačkih limfocita $\mathrm{T}$, čime limfociti B dobivaju prvi signal aktivacije. Pored toga, u ovoj međustaničnoj vezi limfociti $T$ izražavaju molekulu CD40L (CD154), a limfociti B kostimulacijsku CD40 molekulu. Njihovim međudjelovanjem limfociti B dobivaju i kostimulacijski signal. $C D 4^{+} T_{F H}$ stanice pored navedenog luče i citokine potrebne za diferencijaciju limfocita B do plazma stanica ili memorijskih limfocita B. Plazma stanice migriraju u koštanu srž, a memorijske stanice (površinski biljeg CD27) u sekundarna limfna tkiva, čime osiguravaju dugotrajnu specifičnu humoralnu imunost ${ }^{31}$.

Plazma stanice kao završni stupnjevi diferencijacije limfocita $B$, nakon njihova kontakta $s$ antigenom darovatelja, proizvode protutijela (imunoglobuline). Razlikujemo pet osnovnih izotipova ili razreda imunoglobulina (IgM, IgD, IgG, IgA i IgE). Kao topive molekule, protutijela se mogu specifično vezati na antigenske determinante (epitope) posredstvom svojih paratopa (vezna mjesta, Fab fragmenti protutijela). Nadalje, protutijela u svojoj strukturi imaju i dio nazvan Fc fragment s kojim se mogu povezivati na one stanice koje izražavaju odgovarajuće Fc receptore. Time protutijela funkcioniraju kao adaptorske molekule koje prilagođavaju kontakt između izvršnih imunosnih stanica i ciljnih antigenskih struktura. Ove strukture mogu biti i stanice, a njihovo povezivanje naročito posreduju protutijela razreda IgG. Ako se te ciljne stanice nalaze u presatku, protutijela taj presadak oštećuju na dva temeljna načina, poticanjem klasičnog puta aktivacije komplementa te vezanjem efektorskih stanica posredstvom njihovog Fc fragmenta. Aktivacijom komplementa proizvode se ulomci koji djeluju kemotaktično (npr. C5a) i anafilatoksično (npr. C3a, C4a, C5a) te u konačnici citotoksično, tako da ovaj mehanizam pridonosi osobito kroničnom odbacivanju presatka, iako u nekih pacijenata može i smanjiti aloimunosni odgovor. Protutijela naročito napadaju endotel u presatku. Posredstvom Fc fragmenata protutijela oštećenje presatka u najvećoj mjeri uzrokuju makrofazi, no pored njih i druge imunosne stanice koje mogu reagirati s Fc fragmentom prethodno vezanih protutijela u reakciji stanične citotoksičnosti posredovane protutijelima ovisne (engl. ADCC = antibody-dependent cell-mediated cytotoxicity). Kao marker aktivacije komplementa koristi se ulomak C4d, koji se dokazuje analizom bioptata bubrežnog presatka.

\section{Suzbijanje funkcije limfocita B i djelovanja protutijela s lijekovima}

Limfociti B izražavaju površinski biljeg CD20 koji se može iskoristiti za eliminaciju limfocita B u cirkulaciji i smanjenje njihove koncentracije u limfnim organima pomoću lijeka rituksimab, a što su zapravo monoklonska protutijela na CD20 molekulu. Plazma stanice ne izražavaju CD20, zbog čega rituksimab ne može dostatno suzbiti njihovo stvaranje i lučenje DSA, kao niti reakciju odbacivanja posredovanu protutijelima (ABMR), međutim, on može smanjiti razvoj nove antidonorske humoralne imunosti, odnosno de novo stvaranje DSA. Inhibitori proteasoma, primjerice bortezomib, koji se koristi za liječenje od multiplog mijeloma, suzbijaju funkciju plazma stanica ${ }^{12}$.

\section{ISHEMIJSKO-REPERFUZIJSKO OŠTEĆENJE I SUSTAV PRIRODENE IMUNOSTI}

Kod eksplantacije prekida se cirkulacija i organ se stavlja na led, čime nastaje tzv. hladna ishemija, dok tijekom reanastomoza krvnih žila traje tzv. 
topla ishemija organa. Tada se neposredno potiče upalni odgovor, u kojem pored stečene imunosti sudjeluje i sustav prirođene imunosti. Ovaj sustav obuhvaća upalne stanice poput makrofaga, neutrofila i dendritičkih stanica, kao i topive medijatore iz sustava komplementa, stanica NK i nekih citokina. Prema tome, reperfuzija može voditi u oštećenje i propadanje stanica, odnosno u odbacivanje presatka. Ovo ishemijsko-reperfuzijsko oštećenje glavni je uzrok odgođenog preuzimanja funkcije presatka nakon transplantacije, a kasnije je povezano s većom učestalosti reakcija odbacivanja kao i smanjenim preživljenjem presatka.

\section{SUZBIJANJE IMUNOSNE REAKTIVNOSTI LIJEKOVIMA}

Cilj imunosupresivnog liječenja je suzbijanje imunosne aktivnosti radi omogućavanja dobre funkcije i dugotrajnog preživljenja presatka. Imunosupresiju dijelimo na antigen-specifičnu i antigen-nespecifičnu, s time da u klinici uglavnom primjenjujemo antigen-nespecifičnu imunosupresiju, iako bi antigen-specifična bila daleko zahvalnija i za pacijenta bolja. Antigen-specifična imunosupresija odnosila bi se na potiranje imunosne reaktivnosti prema točno određenim antigenima presatka, bez smanjenja opće imunosne reaktivnosti prema drugim antigenima iz okoliša. $S$ druge strane, $u$ antigen-nespecifičnoj imunosupresiji potire se opća aktivnost imunosnog sustava prema svim antigenima iz okoliša, pa tako i prema antigenima samog presatka. Zbog toga je antigen-neovisna imunosupresija povezana s neželjenim nuspojavama koje su mahom rezultat prekomjernog, neadekvatnog rasta mikroorganizama što bi imunosni sustav trebao spriječiti.

Bez limfocita T ne može se odbaciti presadak, ako primatelj nema prirodna protutijela protiv njega, pa je imunosupresivno liječenje prvenstveno usmjereno na slabljenje funkcije limfocita $\mathrm{T}$ (slika 3). U slučaju razvoja humoralne reakcije odbacivanja, protutijela se odstranjuju postupcima plazmafereze ili imunoadsorpcije, a odgovarujućim imunosupresivnim liječenjem sprječava se stvaranje novih DSA. Postoji niz različitih znanstvenih i kliničkih pristupa u provođenju imunosupresije, ali osnovni imunosupresivni protokol najčešće obu- hvaća inhibitor kalcineurina, mikofenolat/ mikofenolnu kiselinu i kortikosteroide, uz indukciju IL-2 blokatorom ili antitimocitnim globulinom. Mehanizmi djelovanja kalcineurinskih i mTOR inhibitora te lijeka belatacept opisani su ranije. Mikofenolat (mofetil mikofenolat ili mikofenolna kiselina) slično azatioprinu djeluje antiproliferativno, inhibicijom sinteze purina, s time da on djeluje samo u aktiviranim limfocitima. Kortikosteroidi (npr. metil-prednizolon) blokiraju ekspresiju gena za citokine u makrofagima i limfocitima te imaju široko, nespe-

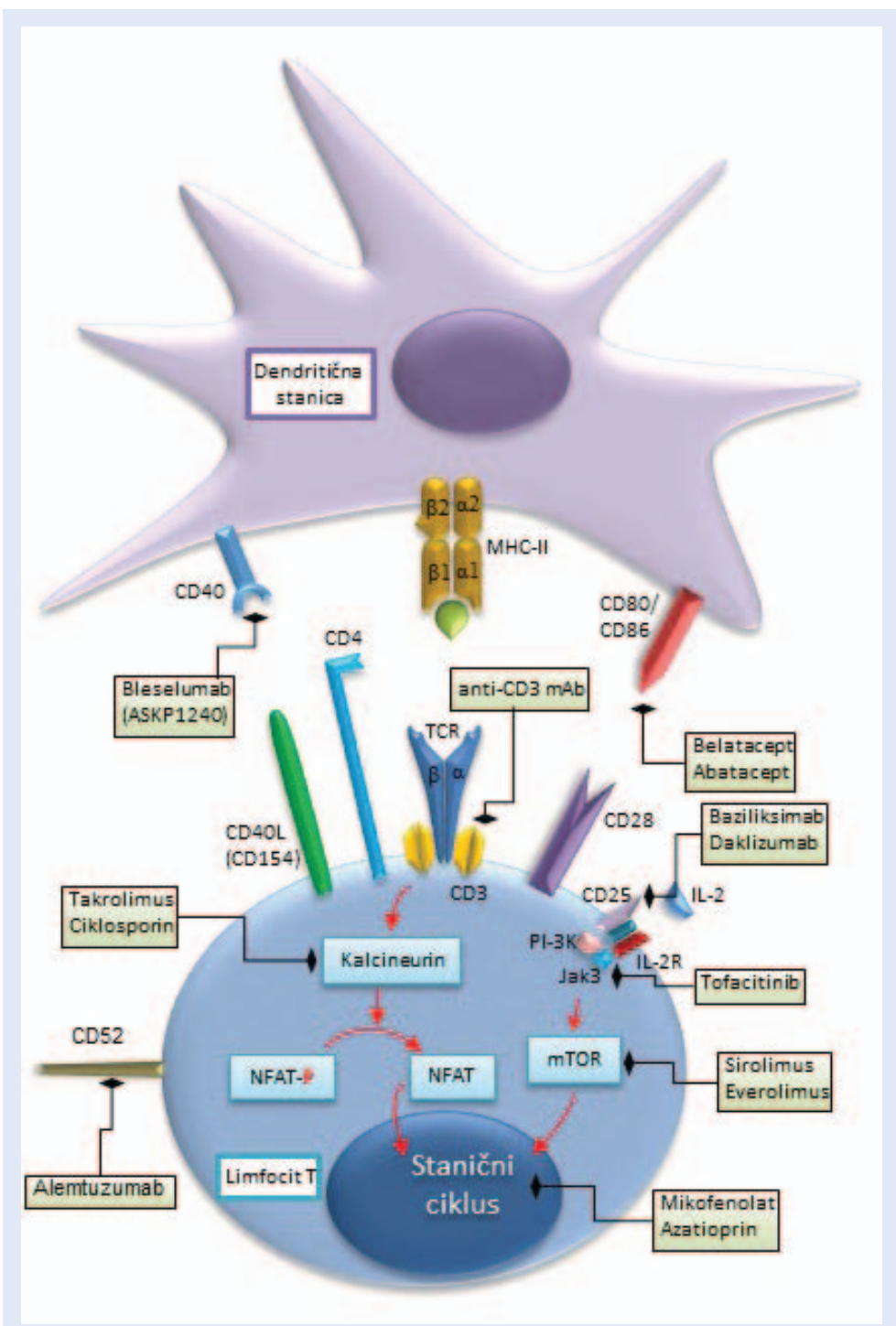

Slika 3. Djelovanje imunosupresivnih lijekova

Slika prikazuje mogućnosti sprječavanja aktivacije i proliferacije limfocita T. Aktivacija limfocita T učinkovito se može inhibirati lijekovima poput inhibitora kalcineurina i blokatora interleukin-2 receptora te blokadom transmembranskog prijenosa signala putem Jak3-kinaza i mTOR-a. Na slici su prikazana i mjesta djelovanja drugih imunosupresivnih lijekova koji se koriste ili ispituju za blokadu aktivacije i proliferacije limfocita T. 
cifično antilimfocitno, imunosupresivno i protuupalno djelovanje. $U$ indukciji imunosupresije najčešće koristimo baziliksimab, monoklonsko protutijelo na $\alpha$ lanac IL-2R koje inhibira proliferaciju limfocita T, ili antitimocitni globulin koji sadrži poliklonska citotoksična protutijela za depleciju limfocita T. U sklopu T limfocitnog receptora nalazi se i CD3 kompleks, koji služi za transmembranski prijenos signala nakon povezivanja $\mathrm{T}$ limfocitnog receptora na HLA molukulu. U imunosupresivnom liječenju koristilo se blokadno monoklonsko protutijelo OKT3 koje ometa prijenos signala i aktivaciju limfocita T, no izbačeno je iz upotrebe zbog niza štetnih nuspojava.

Kada je indicirano snažnije suzbijanje imunosne reakcije, može se primijeniti liječenje intravenskim imunoglobulinima, plazmaferezom, imunoadsorpcijom, alemtuzumabom (anti-CD52 monoklonsko protutijelo koje nalazimo na limfocitima T, limfocitima B, monocitima i makrofagima), rituksimabom (anti-CD20 monoklonsko protutijelo), bortezomibom (inhibitor proteasoma), ekulizumabom i C1 inhibitorom (inhibitori komplementa), blokatorom IL-6 receptora (tocilizumab), i enzim piogenog streptokoka koji razgrađuje imunoglobulin-G (IdeS), a postoji i mogućnost splenektomije ${ }^{32}$. Pored protokola za desenzibilizaciju, kojima se odstranjuje ili značajno smanjuje titar DSA u potencijalnog primatelja bubrega, koriste se i protokoli za imunomodulaciju i razvoj tolerancije, a postoji mogućnost presađivanja bubrega u okviru posebnih programa razmjene organa. Kod dodjele organa može se dati prednost kandidatima koji su visokosenzibilizirani na HLA antigene, primjerice u programu prihvatljive podudarnosti (engl. acceptable mismatch program) ili omogućiti presađivanje $u$ okviru programa razmjene bubrega između parova nepodudarnih primatelja i darovatelja organa (engl. kidney paired donation) $)^{12,15}$.

\section{TOLERANCIJA}

Cilj transplantacijske medicine je postići toleranciju, odnosno odsustvo imunosnog odgovora na aloantigene presatka bez kronične imunosupresije i uz održanu normalnu opću imunost. Time bi se smanjio rizik od neželjenih djelovanja lijekova, razvoja infekcija i nastanka zloćudnih tumora. Razlikujemo centralnu i perifernu toleranciju. Centralna tolerancija razvija se u timusu tijekom sazrijevanja limfocita T u procesima nazvanim pozitivna i negativna selekcija. Pozitivna selekcija podrazumijeva preživljavanje onih limfocita T koji uspijevaju prepoznati vlastite HLA molekule, bilo razreda I ili razreda II. Oni limfociti T koji imaju nasumično stvoren takav receptor koji ne može prepoznati HLA molekule, odumiru apoptozom. Nakon toga uslijedi proces negativne selekcije, u kojemu se prethodno pozitivno probrani limfociti T na reaktivnost prema HLA molekulama testiraju na temelju afiniteta za vezanje identičnih HLA molekula koje sada izražavaju vlastite peptide. Limfociti T koji prejako reagiraju prema vlastitim HLA molekulama u kojima se nalaze peptidi, odumiru apoptozom, a preživljavaju oni koji pokazuju umjerenu ili slabu reaktivnost. Druga vrsta tolerancije je periferna tolerancija, u kojoj se potencijalno autoreaktivni limfociti T, a koji prethodno nisu adekvatno negativno selektirani u timusu, suprimiraju djelovanjem perifernih citokina, npr. TGF- $\beta$ i IL-10 podrijetlom iz regulacijskih limfocita T. Periferna tolerancija obuhvaća i procese anergizacije i delecije limfocita $\mathrm{T}$ koji uslijede nakon prepoznavanja antigena u odsustvu kostimulacijskih ili pomoćnih diferencijacijskih signala neophodnih za potpunu aktivaciju stanica. Normalno stanice presatka ne izražavaju ove kostimulacijske signale, pa ne mogu aktivirati izravno limfocite primatelja, no suputnički donorski leukociti ih mogu izražavati i time dovesti do aktivacije antidonorske imunosti. Postoje i inhibicijske membranske molekule koje negativno reguliraju funkciju efektorskih stanica poput CTLA4 ili PD1 molekula (engl. programmed cell death protein 1), čije poticanje vodi u inhibiciju ili supresiju limfocitnih funkcija. Za razvoj donor-specifične tolerancije istražuje se više protokola koji mogu uključivati različite stupnjeve prethodne pripreme te infuziju donorskih hematopoetskih matičnih stanica radi uspostave privremenog ili trajnog kimerizma u primatelja ${ }^{12}$. U tim uvjetima primatelj bi tolerirao organ darovatelja, ali i vlastitih tkiva zbog centralnog odstranjenja aloreaktivnih limfocita T (timus) negativnom selekcijom i mehanizama periferne tolerancije. Mehanizmi periferne tolerancije uključuju deleciju aloreaktivnih limfocita T, indukciju stanja energije funkcionalnom inaktivacijom limfocita $\mathrm{T}$ i regulacijom ili supresijom limfocita $\mathrm{T}$ pomoću drugih stanica ili 
čimbenika. Istražuje se više strategija, primjerice blokadu kostimulacije i primjenu regulacijskih limfocita (Treg) specifičnih za donorske antige$n e^{12,33}$.

\section{ZAKLJUČCI}

HLA molekula je dominantan antigen za razvoj reakcije odbacivanja posredovane stanicama i protutijelima. Znanstvene spoznaje o transplantacijskoj reakciji i mehanizmima djelovanja imunosupresivnih lijekova čine temelj za unaprjeđenje strategija imunosupresivnog liječenja te dijagnostičkih testova za utvrđivanje individualnog imunosnog rizika, ali i intenziteta imunosne reakcije. Individualizacijom imunosupresije možemo poboljšati kvalitetu života te preživljenje pacijenata i presatka. Cilj transplantacijske medicine je razvoj dugotrajne imunosne tolerancije na presadak koja bi omogućila sigurno i pouzdano suzbijanje neželjenog imunosnog odgovora na antigene presatka, bez smanjenja željenog imunosnog odgovora na druge antigene, kao što su uzročnici bolesti.

Izjava o sukobu interesa: Autori izjavljuju da ne postoji sukob interesa

\section{LITERATURA}

1. Billingham RE, Brent L, Medawar PB. Quantitative studies on tissue transplantation immunity. II. The origin, strength and duration of actively and adoptively acquired immunity. Proc R Soc B 1954;143:58-80.

2. Merrill JP, Murray JE, Harrison JH, Guild WR. Successful Homotransplantation of the Human Kidney Between Identical Twins. JAMA 1956;160:277.

3. Joseph E. Murray - Nobel Lecture, December 8, 1990 The First Successful Organ Transplants in Man [cited 2020 Mar 1]. Available from: https://www.nobelprize. org/prizes/medicine/1990/murray/25012-joseph-emurray-nobel-lecture-1990/.

4. Murphy K, Weaver C. Antigen presentation to T Iymphocytes. In: Janeway's Immunobiology, $9^{\text {th }}$ Edition. New York and London: Garland Science, 2017;213-30.

5. Murphy K, Weaver C. Autoimmunity and transplantation. In: Janeway's Immunobiology, $9^{\text {th }}$ Edition. New York and London: Garland Science, 2017;643-96.

6. Trobonjača Z, Živčić-Ćosić S, Lisjak J. Imunobiologija presađivanja bubrega. Medicina Fluminensis 2010;46: 424-33.

7. Pratt JR, Basheer SA, Sacks SH. Local synthesis of complement component $\mathrm{C} 3$ regulates acute renal transplant rejection. Nat Med 2002;8:582-7.

8. Murphy K, Weaver C. Responses to alloantigens and transplant rejection. In: Janeway's Immunobiology, $9^{\text {th }}$ Edition. New York and London: Garland Science, 2017; 683-99.
9. Opelz G. Correlation of HLA matching with kidney graft survival in patients with or without cyclosporine treatment. Transplantation 1985;40:240-3.

10. Doxiadis IIN, de Fijter JW, Mallat, MJK, Haasnoot GW, Ringers J, Persijn GG et al. Simpler and equitable allocation of kidneys from postmortem donors primarily based on full HLA- DR compatibility. Transplantation 2007;83:1207-13.

11. Terasaki PI. Histocompatibility. In: History of Transplantation. Los Angeles: UCLA, 1991;497-510.

12. Montgomery RA, Tatapudi VS, Leffell MS, Zachary AA. HLA in transplantation. Nat Rev Nephrol. 2018;14:55870.

13. Kramer CSM, Israeli M, Mulder A, Doxiadis IIN, Haasnoot GW, Heidt $S$ et al. The long and winding road towards epitope matching in clinical transplantation. Transpl Int 2019;32:16-24.

14. HLA Nomenclature. HLA alleles numbers [cited 2020 May 1]. Available from: http://hla.alleles.org/nomenclature/stats.html.

15. Heidt S, Haasnoot GW, van Rood JJ, Witvliet MD, Claas FHJ. Kidney allocation based on proven acceptable antigens results in superior graft survival in highly sensitized patients. Kidney Int 2018;93:491-500.

16. Warren EH, Greenberg PD, Riddell SR. Cytotoxic T-Iymphocyte-defined human minor histocompatibility antigens with a restricted tissue distribution. Blood 1998;91: 2197-207.

17. Murphy K, Weaver C. T-cell-mediated immunity. In: Janeway's Immunobiology, $9^{\text {th }}$ Edition. New York and London: Garland Science, 2017;345-95.

18. Murphy K, Weaver C. Antigen recognition by B-cell and T cell receptors. In: Janeway's Immunobiology, $9^{\text {th }}$ Edition. New York and London: Garland Science, 2017;139-70.

19. Banchereau J, Steinman RM. Dendritic cells and the control of immunity. Nature 1998;392:245-52.

20. Sayegh MH, Turka LA. The role of T-cell costimulatory activation pathways in transplant rejection. $\mathrm{N}$ Engl J Med 1998;338:1813-21.

21. Radvanyi LG, Shi Y, Vaziri H, Sharma A, Dhala R, Mills GB et al. CD28 costimulation inhibits TCR-induced apoptosis during a primary T cell response. J Immunol 1996;156: 1788-98.

22. Larsen CP, Pearson TC, Adams AB, Tso P, Shirasugi N, Strobert E et al. Rational development of LEA29Y (belatacept), a high-affinity variant of CTLA4-Ig with potent immunosuppressive properties. Am J Transplant 2005;5: 443-53.

23. Vincenti F. Costimulation blockade-what will the future bring? Nephrol Dial Transplant 2007;22:1293-6.

24. Walunas TL, Lenschow DJ, Bakker CY, Linsley PS, Freeman GJ, Green JM et al. CTLA-4 can function as a negative regulator of T cell activation. Immunity 1994;1:405-13.

25. Hodi FS. Cytotoxic T-lymphocyte-associated antigen-4. Clin Cancer Res 2007;13:5238-42.

26. Clarkson MR, Sayegh MH. T-cell costimulatory pathways in allograft rejection and tolerance. Transplantation 2005;80:555-63.

27. Murphy $\mathrm{K}$, Weaver $\mathrm{C}$. Antigen recepetor signaling and Iymphocyte activation. In: Janeway's Immunobiology, $9^{\text {th }}$ Edition. New York and London: Garland Science, 2017; 265-79. 
28. Bierer BE, Holländer G, Fruman D, Burakoff SJ. Cyclosporin A and FK506: molecular mechanisms of immunosuppression and probes for transplantation biology. Curr Opin Immunol 1993;5:763-73.

29. Brown EJ, Albers MW, Shin TB, Ichikawa K, Keith CT, Lane WS et al. A mammalian protein targeted by G1arresting rapamycin-receptor complex. Nature 1994; 369:756-8.

30. Murphy K, Weaver $\mathrm{C}$. The humoral immune response. In: Janeway's Immunobiology, $9^{\text {th }}$ Edition. New York and London: Garland Science, 2017;399-441.
31. Murphy K, Weaver C. Integrated dynamics of innate and adaptive immunity. In: Janeway's Immunobiology, $9^{\text {th }}$ Edition. New York and London: Garland Science, 2017;445-88.

32. Montgomery RA, Lonze BE, Tatapudi VS. IgG degrading enzyme of Streptococcus pyogenes: an exciting new development in desensitization therapy. Transplantation 2018;102:2-4.

33. Morath C, Schmitt A, Kälble F, Zeier M, Schmitt M, Sandra-Petrescu $F$ et al. Cell therapeutic approaches to immunosuppression after clinical kidney transplantation. Pediatr Nephrol 2018;33:199-213. 